\title{
PENGEMBANGAN SISTEM TIMER DIKENDALIKAN \\ COUNTER DIGITAL DENGAN SENSOR INFRA MERAH \\ BERBASIS MIKROKONTROLER AT89C51
}

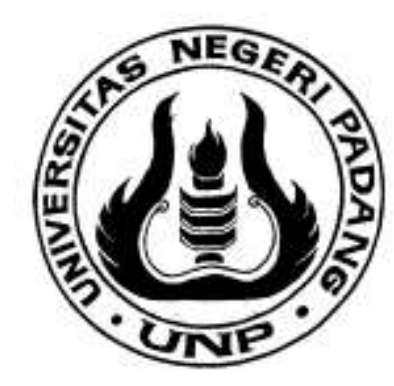

Disampaikan Pada Seminar Nasional Fisika

Universitas Andalas

di Padang Tanggal 03 September 2007

Oleh

Drs. Asrizal, M.Si

FAKULTAS MATEMATIKA DAN ILMU PENGETAHUAN ALAM UNIVERSITAS NEGERI PADANG 


\title{
PENGEMBANGAN SISTEM TIMER DIKENDALIKAN COUNTER DIGITAL DENGAN SENSOR INFRA MERAH BERBASIS MIKROKONTROLER AT89C51
}

\author{
Asrizal \\ Staf Pengajar Jurusan Fisika FMIPA Universitas Negeri Padang
}

\begin{abstract}
Time is an important Physical quantities because many Physics events connect with that time such as periodic motion. There are many periodic motion events in Physics such as circular motion, physical pendulum, spring oscillation, etc. Developing a system to determine parameters of periodic motion is important to be conducted to get an accuracy and precision of system. The general purpose of this research was to develop a design digital timer controlled counter with infrared sensor based microcontroller. On the other hand, the specifically purposes of research were to determine accuracy and precision of time and count display tool of system, and to determine accuracy and precision of system in determining parameters of uniform circular motion. This research could be classified into laboratory experiment. The data collection technique used direct and indirect measurement. The Data was analyzed by using graph technique and error theory analysis. Based on data analysis was founded two main result of this research as follow: 1). Accuracy and precision of system to count event and to measure time was high, and 2). Timer controlled counter system can determine parameters of uniform circular motion well.
\end{abstract}

Key Word: Timer, counter, infrared, microcontroller, accuracy, precision

\section{Pendahuluan}

Timer merupakan salah satu instrumen yang penting karena banyak diterapkan dalam kehidupan sehari-hari. Beberapa penerapan timer dalam kehidupan seperti pengaturan waktu pada oven, penghitungan waktu seorang pelari dari titik start sampai finish, menghitung waktu yang diperlukan mobil bergerak dari satu lap ke lap terakhir, menghitung waktu yang diperlukan suatu benda bergerak dari suatu posisi ke 
posisi lain dan sebagainya. Untuk menghitung waktu dari suatu peristiwa diperlukan suatu instrumen timer yang akurat dan teliti.

Dalam fisika pengukuran terhadap waktu sering dilakukan karena begitu banyak peristiwa fisika yang berubah dengan waktu. Sebagai contoh pengukuran waktu pada gerak lurus horizontal, gerak jatuh bebas, gerak melingkar, gerak parabola, gerak osilasi harmonik, pengisian dan pengosongan kapasitor, peluruhan zat radioaktif dan sebagainya. Dalam menentukan nilai suatu parameter fisika maupun hubungan antara variabel sering didahului dengan pengukuran terhadap waktu.

Untuk pengukuran waktu di laboratorium seringkali digunakan stopwatch, namun instrumen ini memiliki beberapa kelemahan seperti bekerja secara manual, sering terjadi kesalahan dalam pembacaan, kurang tepatnya penekanan tombol start saat benda mulai bergerak dan tombol stop saat benda berhenti. Start stop timer digital merupakan suatu instrumen elektronik yang dapat diterapkan untuk mengatasi permasalahan ini.

Pada eksperimen gerak periodik seperti gerak melingkar, ayunan matematis, dan getaran pegas disamping diperlukan pengukuran waktu juga dilakukan penentuan jumlah cacahan. Pengukuran waktu dan jumlah cacahan dapat digunakan untuk menentukan perioda dan frekuensi dari suatu gerak gerak periodik. Pada saat ini masih kegiatan eksperimen gerak periodik yang melakukan pengukuran waktu menggunakan stopwatch dan menghitung jumlah cacahan secara manual.

Pengembangan suatu sistem untuk dapat menentukan jumlah cacahan sesuai dengan pilihan dan mengukur waktu secara otomatis perlu dilakukan untuk mendapatkan hasil eksperimen yang lebih baik. Dengan dasar ini peneliti merasa tertarik untuk mengembangkan sistem timer dikendalikan counter digital dengan sensor inframerah berbasis mikrokontroler AT89C51. Sistem yang dibangun dari mikrokontroler memiliki beberapa keunggulan antara lain: memerlukan sedikit 
komponen elektronika, ukuran dapat lebih kecil, dapat diprogram ulang, lebih mudah ditampilkan dalam bentuk digital, dan mudah diinterfacing ke komputer.

Berdasarkan latar belakang yang telah dikemukakan dapat dirumuskan masalah dalam penelitian ini yaitu: "Apakah sistem timer dikendalikan counter digital dengan sensor inframerah berbasis mikrokontroler AT89C51 memiliki karakteristik statik tinggi dan dapat digunakan untuk menentukan parameter gerak melingkar beraturan ?. Karakteristik statik sistem yang diselidiki hanya ketepatan dan ketelitian, sedangkan parameter gerak melingkar beraturan meliputi: frekuensi, kecepatan sudut, danm kecepatan linear.

Tujuan dari penelitian ini adalah untuk menentukan ketepatan dan ketelitian dari sistem untuk mencacah peristiwa dan mengukur waktu dari jumlah cacahan yang dipilih; untuk menentukan hubungan waktu dengan jumlah cacahan, menentukan kecepatan sudut, dan menentukan hubungan kecepatan sudut dan kecepatan linear dengan tegangan yang diberikan pada motor DC pada gerak melingkar beraturan. Hasil dari penelitian ini diharapkan memberikan kontribusi pada laboratorium fisika untuk pengukuran waktu dan penentuan jumlah cacahan, peneliti sebagai sumber ide dan referensi untuk pengembangan penelitian tentang timer, dan instansi-instansi yang memerlukan pengukuran waktu.

\section{Teori}

Waktu didefinisikan sebagai interval antara dua peristiwa, dan pengukuran dari interval waktu ini dengan membuat perbanding dengan beberapa peristiwa yang dapat diulang (Dally, J.W: 1993). Pengukuran waktu antara dua peristiwa adalah sangat penting dalam beberapa studi eksperimental (Doebelin, E.O: 1990). Dalam banyak kegiatan eksperimen dalam bidang fisika pengukuran waktu secara tepat dan teliti sering dilakukan. 
Start stop timer digital merupakan suatu jenis instrumen elektronika dengan waktu dapat dikontrol melalui tombol start untuk memulai dan stop untuk menghentikan suatu peristiwa. Pengontrolan start stop dari timer dapat dilakukan melalui sensor inframerah.

Sistem start stop timer digital dibangun dari sensor inframerah, rangkaian pengolah sinyal, dan display digital. Rangkaian elektronika yang digunakan terdiri dari multivibrator astabil sebagai pemancar, multivibrator monostabil sebagai penerima, mikrokontroler AT89C51 sebagai counter dan sebagai timer, decoder dengan display digital, dan catu daya teregulasi.

Sensor inframerah merupakan suatu piranti gallium arsenide (GaAs) yang memancarkan cahaya dalam daerah inframerah biasanya di luar daerah pandangan manusia (Leach, D.P: 1986). Inframerah merupakan cahaya yang tidak tampak dengan panjang gelombang sekitar $7000 \mathrm{~A}^{\mathrm{o}}$. Dengan panjang gelombang ini menyebabkan inframerah tidak tampak oleh mata, namun radiasi panas yang ditimbulkannya masih dapat terasa atau dideteksi.

Cahaya inframerah mempunyai panjang gelombang yang panjang, namun tetap tidak dapat menembus bahan-bahan yang tidak dapat melewatkan cahaya yang nampak sehingga tetap mempunyai karakteristik seperti halnya cahaya yang nampak oleh mata (Susanto, W.K: 2000). Dengan sifat seperti ini menyebabkan sensor inframerah dapat digunakan sebagai pemancar.

Sensor inframerah juga dapat berperan sebagai pemancar. Komponen ini dapat berupa photodioda atau phototransistor yang akan mengkonversi energi cahaya inframerah menjadi pulsa-pulsa sinyal listrik. Komponen ini harus mampu mengumpulkan sinyal inframerah sebanyak mungkin sehingga pulsa sinyal listrik yang dihasilkan kualitasnya cukup baik (Susanto, W.K: 2000). 
Sensor inframerah dalam bentuk $I R$ LED dipasang pada keluaran rangkaian multivibrator astabil berfungsi sebagai pemancar. Rangkaian astabil adalah tipe osilasi elektronik yang menghasilkan tegangan secara terus menerus dari kondisi tinggi ke rendah kemudian dari rendah ke tinggi dan seterusnya (Plant, M: 1985). Disisi lain inframerah dalam bentuk IR module dipasang pada rangkaian multivibrator monostabil berfungsi sebagai penerima. Rangkaian monostabil adalah suatu rangkaian yang setiap ditrigger akan memberikan tegangan keluaran tinggi untuk suatu waktu yang belum ditentukan sebelumnya, kemudian setelah selang waktu tertentu, tegangan keluaran rangkaian akan kembali pada kondisi normal (Plant, M: 1985).

Penentuan kapan start dan stop dari timer digital diprogram melalui mikrokontroller. Suatu mikrokontroler adalah suatu piranti chip tunggal yang berisi memori untuk infomasi program dan data yang mempunyai logika untuk pembacaan kontrol input terprogram, pemanipulasian data, dan pengiriman output. Dengan kata lain mikrokontroler dibangun sebagai suatu interface untuk input/output yang mampu digunakan untuk sensor, aktuator dan komunikasi (Spasov, P : 1996). Pendapat ini diperkuat oleh Iovine, J (2000) yang mengungkapkan “ Kemampuan mikrokontroller untuk menyimpan program tertentu membuatnya lebih unggul. Dalam hal ini program dari suatu mikrokontroller digunakan untuk membuat keputusan didasarkan pada situasi dan seleksi sebelumnya. Mikrokontroller memiliki kemampuan untuk membentuk fungsi matematika dan logika".

Suatu fasilitas penting yang terdapat pada mikrokontroller adalah timer. Timer ini merupakan suatu seri dari flip flop yang dibagi dengan dua dan menerima suatu input sinyal sebagai sumber clock. Timer ini digunakan untuk empat keperluan yaitu untuk pengontrolan waktu, untuk keperluan interval pewaktuan (interval timing), 
untuk penghitungan peristiwa (event counting), dan untuk menghasilkan baudrate (Mackenzie, S: 1995).

Mikrokontroler sebagai start-stop timer dikendalikan oleh dua pasang transmiter dan receiver. Perhitungan waktu dimulai saat terjadi kondisi tinggi sesaat pada bagian start yang dihasilkan oleh multivibrator monostabil sehingga memicu timer untuk mulai bekerja. Kondisi tinggi ini terjadi bila sensor IR LED I sebagai transmiter dan IR module I sebagai receiver terhalangi. Sebaliknya saat sensor $I R$ LED II dan IR module II dihalangi akan menghasilkan kondisi tinggi sesaat pada bagian stop yang akan memicu mikrokontroler untuk berhenti melakukan perhitungan waktu.

Jalannya waktu pada start stop timer digital ditampilkan pada display digital. Display ini terdiri decoder, saklar transistor, dan seven segment. Decoder merupakan suatu rangkaian logika yang menerima suatu set input yang melukiskan bilangan biner dan hanya mengaktifkan output yang berhubungan dengan bilangan input (Tocci, R.J: 1995). Penggerak decoder seven segment adalah IC decoder yang dapat digunakan untuk menggerakkan indikator seven segment (Malvino: 1995).

\section{Metodologi}

Desain sistem timer dikendalikan counter digital berbasis mikrokontroler terdiri dari dua bagian yaitu perangkat keras (hardware) dan perangkat lunak (software). Desain perangkat keras bertujuan untuk mengembangkan sistem timer dikendalikan counter melalui kombinasi sensor inframerah dan rangkaian dasar elektronika. Disisi lain, desain perangkat lunak bertujuan untuk mengembangkan program assembly yang akan disimpan pada mikrokontroler sehingga sistem akan bekerja sesuai dengan yang diharapkan. Kedua desain ini dikombinasikan sehingga dapat membentuk suatu sistem timer dikendalikan counter digital yang bekerja secara otomatis, utuh, dan kompatibel. 
Perangkat keras dari sistem pengontrolan waktu diskrit ini terdiri dari sensor inframerah, rangkaian pemancar inframerah, rangkaian penerima inframerah, mikrokontroler sebagai counter, mikrokontroler sebagai timer, display digital, dan catu daya teregulasi. Secara umum diagram blok dari sistem pengaturan waktu diskrit berbasis mikrokontroler diperlihatkan pada Gambar 1 :

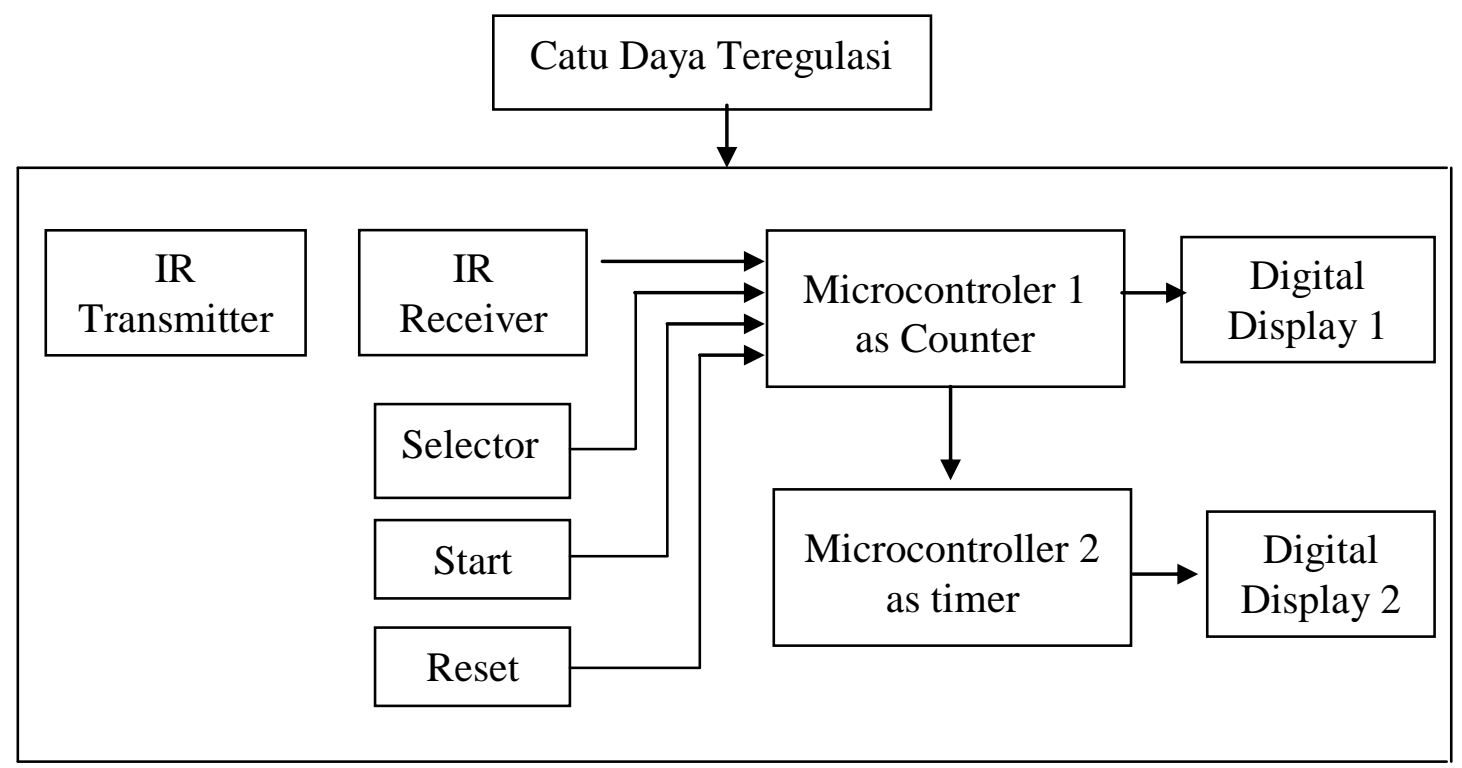

Gambar 1. Diagram Blok dari Sistem Timer Dikendalikan Counter

Desain software diarahkan pada pengembangan program untuk mengoperasikan mikrokontroler sesuai dengan keperluan. Pemograman dapat menggunakan bahasa assembly, $\mathrm{C}$ dan bahasa pemogram lainya yang kompatibel. Dalam penelitian bahasa pemograman yang digunakan adalah bahasa Assembly yang ditulis menggunakan software Read51. Bahasa assembly merupakan suatu bahasa yang digunakan oleh programmer untuk mengetahui kode-kode bahasa mesin (Ayala K. J :1997). Dalam sistem timer dikendalikan counter, mikrokontroler diprogram sebagai pewaktu (timer) dan sebagai pencacah (counter) digital.

Algoritma program untuk pencacah secara umum dapat dilukiskan melalui beberapa 7 tahap yaitu: 1 . Inisialisasi program, 2. Tentukan data cacahan, 3. Masukan hasil cacahan, 4. Konversi heksa ke BCD, 5. Nyalakan seven segment, 6. Tunda $1 \mathrm{~ms}$, dan 7. Akhir program. Disisi lain algoritma untuk timer terdiri dari 5 tahap yaitu: 
Inisialisasi program, 2. konversi heksa ke BCD, 3. Nyalakan seven segment, 4). Tunda $1 \mathrm{~ms}$, dan 5). Akhir program.

Dalam penelitian ini instrumen yang digunakan untuk mendapatkan data meliputi alat ukur waktu seperti scaler counter sebagai alat standar untuk mengukur waktu dan multimeter digital untuk mengukur tegangan dan mencek rangkaian. Disamping itu diperlukan komponen dan bahan seperti sensor inframerah, IC 555, mikrokontroler AT89C51, decoder, transistor, dioda, tahanan, kapasitor dan lain-lain. Untuk menentukan ketepatan dalam pengukuran perlu dilakukan kalibrasi dengan alat ukur standar dan melakukan pengukuran terhadap komponen yang digunakan. Untuk menentukan ketelitian dilakukan pengukuran beberapa kali.

Teknik pengumpulan data yang akan digunakan pada penelitian ini adalah secara pengukuran. Teknik pengukuran meliputi dua bagian yaitu pengukuran secara langsung terhadap variabel yang akan diukur dan pengukuran secara tidak langsung. Pengukuran secara langsung artinya variabel yang akan diketahui diukur secara langsung misalnya waktu diukur dengan stopwatch. Pengukuran tidak langsung artinya pengukuran terhadap suatu variabel dengan cara melakukan pengukuran terhadap variabel lain sedangkan variabel yang diinginkan ditentukan kemudian seperti penentuan kemiringan garis lurus dengan melakukan pengukuran terhadap waktu alat standar dan waktu alat yang dibuat.

Dalam penelitian ini variabel yang diukur secara langsung adalah waktu dan jumlah cacahan yang terbaca pada sistem timer dikendalikan counter. Sementara itu variabel yang diukur secara tidak langsung dalam penelitian ini adalah kemiringan garis lurus dari hubungan antara waktu alat standar dengan waktu alat yang dibuat, kecepatan sudut, dan kecepatan linear. Kemiringan dari garis lurus ini akan memberikan informasi bagaimana hubungan waktu yang terdapat pada sistem dengan yang terbaca pada alat standar.

Data yang didapat dari hasil pengukuran dianalisis secara grafik dan statistik. Tujuan utama dari grafik adalah untuk memberikan kesan visual dari hasil. Dalam praktek fisika, grafik memiliki tiga kegunaan utama yaitu : untuk menentukan harga beberapa besaran, sebagai alat bantu visual, dan untuk melukiskan hubungan antara 
dua variabel yang diperoleh dari pengukuran atau perhitungan untuk beberapa nilai parameter lain.

Data yang menyangkut hubungan antara variabel, atau pengaruh suatu variabel terhadap variabel lain ditampilkan dalam bentuk grafik. Plot terhadap data dilakukan menggunakan program microsoft excel. Melalui plot data dapat diketahui hubungan antara variabel bebas dengan variabel terikat, bentuk pendekatan persamaan dari grafik yang dihasilkan, variansi dan standar deviasi. Bila pendekatan garis dari hubungan antara dua variabel adalah linear maka dapat ditentukan nilai awal dan kemiringan dari garis lurus. Disisi lain, persentase simpangan antara hasil pengukuran dengan hasil perhitungan, ketepatan dan ketelitian dari hasil pengukuran ditentukan teori kesalahan.

Ketepatan merupakan tingkat kesesuaian atau dekatnya suatu hasil pengukuran terhadap harga sebenarnya (Cooper, W.D: 1985). Ketepatan dari sistem pengetauran waktu diskrit ditentukan dari persentase kesalahan. Persentase kesalahan (percent error) merupakan persentase simpangan antara harga besaran yang diukur dengan nilai yang dipercaya (expected value).

Ketepatan relatif (relative accuracy) dari suatu sistem pengukuran dapat ditentukan melalui kesalahan menggunakan persamaan :

$$
A=1-\left|\frac{Y n-X n}{Y n}\right|
$$

Pada persamaan A menyatakan akurasi relatif yang sering dikenal dengan ketepatan relatif (Jones, L.D: 1995). Ketepatan dalam bentuk persentase ketepatan (percent accucary) dapat ditentukan melalui persamaan

$$
\mathrm{A} \%=100 \% \text { - Persentase kesalahan }=\mathrm{A} \times 100
$$

Ketelitian dari suatu pengukuran adalah suatu kuantitas atau angka yang menunjukkan berapa dekatnya hasil dari set pengukuran berulang dari variabel dengan sama dengan rata-rata set pengukuran (Jones, L.D: 1995). Ketelitian dapat diekspresikan dalam bentuk matematika seperti:

$$
\text { Ketelitian }=1-\left|\frac{\mathrm{Xn}-\overline{\mathrm{X}} \mathrm{n}}{\overline{\mathrm{X}} \mathrm{n}}\right|
$$

Dimana, $X_{n}=$ nilai dari pengukuran ke $\mathrm{n}$ dan $\overline{\mathrm{Xn}}=$ rata-rata dari set $\mathrm{n}$ pengukuran. 


\section{Hasil dan Pembahasan}

Sesuai dengan tujuan yang telah ditetapkan, maka pada penelitian ini didapatkan dua hasil utama. Pertama, ketepatan dan ketelitian dari sistem timer dikendalikan counter dalam mencacah dan mengukur waktu. Kedua, parameter dan hubungan antara besaran fisika pada gerak melingkar beraturan.

\section{Ketepatan dan Ketelitian Dari Sistem Timer Dikendalikan Counter}

Ketepatan jumlah cacahan dari counter ditentukan dengan memilih salah satu selektor jumlah cacahan dan menghitung jumlah cacahan secara manual. Ketelitian ditentukan dari penentuan jumlah cacahan secara berulang untuk setiap pemilihan jumlah cacahan. Dari hasil pengujian didapatkan jumlah cacahan yang terbaca pada display digital sesuai dengan jumlah perhitungan secara manual. Dengan demikian ketepatan penentuan jumlah cacahan dari sistem $100 \%$ dan ketelitian sistem adalah 1,00 yang dapat dikategorikan tinggi.

Ketepatan sistem dalam mengukur waktu ditentukan berapa dekatnya waktu yang terbaca oleh sistem dengan waktu yang terbaca pada scaler counter sebagai alat ukur waktu standar. Disisi lain ketelitian dari sistem ditentukan dari pengukuran berulang sebanyak 10 kali untuk dua pilihan jumlah cacahan masing-masing 50 dan 100 cacahan. Dari pengukuran waktu didapatkan persentase simpangan rata-rata $0,259 \%$, dan ketepatan rata-rata 99,741\%. Ketelitian rata-rata sistem untuk cacahan 50 adalah 0,990, sedangkan untuk cacahan 100 adalah 0,992. Dari data ini dapat disimpulkan bahwa ketepatan dan ketelitian sistem dalam mengukur waktu juga termasuk pada kategori tinggi.

Dari data pengukuran waktu menggunakan sistem timer dengan menggunakan scaler counter juga dapat diplot hubungan waktu dari kedua alat ukur tersebut. Hasil plot data dapat diperhatikan pada Gambar 2 


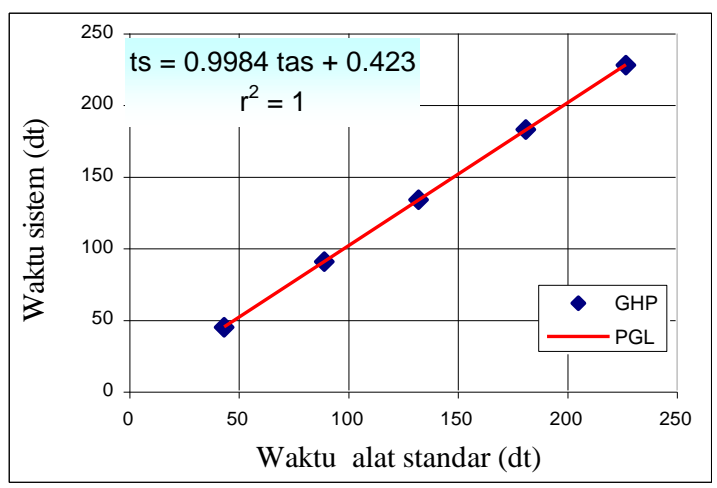

Gambar 2. Hubungan Antara Waktu Sistem Dengan Alat Standar

Dari Gambar 2 dapat dikemukakan bahwa waktu yang terbaca pada sistem timer dikendalikan counter sebanding dengan waktu yang terbaca pada scaler counter. Melalui pendekatan garis lurus didapat hubungan antara waktu pada sistem dengan waktu pada scaler counter dalam bentuk:

$$
\mathrm{t}_{\mathrm{s}}=0,998 \mathrm{t}_{\mathrm{as}}+0,423
$$

Pada persamaan 4, angka 0,998 menunjukan kemiringan dari garis lurus, dan angka 0,423 dt menunjukan nilai awal dari bacaan waktu sistem timer pada saat bacaan scaler counter nol. Dengan nilai gradien mendekati 1 menunjukan nilai waktu yang terukur oleh sistem mendekati sama dengan scaler counter. Koefisien determinasi dari hubungan kedua waktu tersebut adalah 1 . Hal ini berarti $100 \%$ perubahan waktu pada sistem timer sesuai dengan perubahan waktu pada scaler counter

\section{Penentuan Parameter Gerak Melingkar Beraturan}

Penentuan kecepatan sudut dari gerak melingkar beraturan dilakukan dengan menetapkan gerakan motor pada suatu kecepatan, kemudian memvariasikan jumlah cacahan yang terdiri dari 50,100, 150, 200, dan 250. Untuk setiap jumlah cacahan dilakukan pengukuran waktu. Dari hasil pengukuran waktu dan jumlah cacahan dapat ditentukan frekuensi dan perioda dari gerak melingkar beraturan. Kecepatan sudut dari gerak melingkar ditentukan dari hubungannya dengan frekuensi putar. Hubungan 
antara waktu dengan jumlah cacahan, dan hubungan antara kecepatan sudut dengan waktu diperlihatkan pada Gambar 3

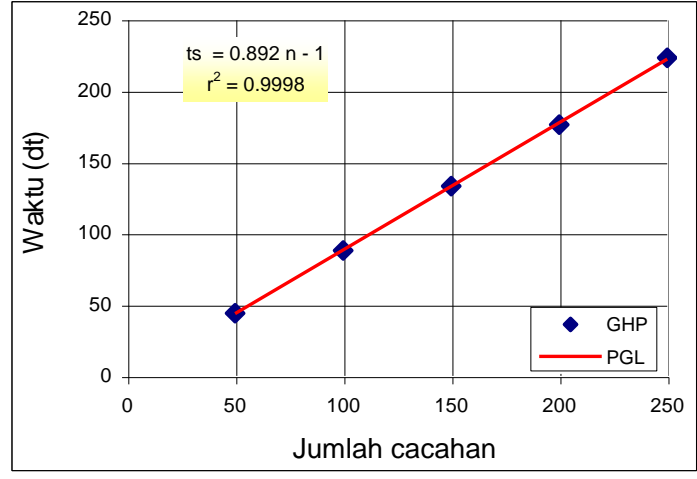

Gbr 3a. Hubungan waktu dengan jumlah cacahan

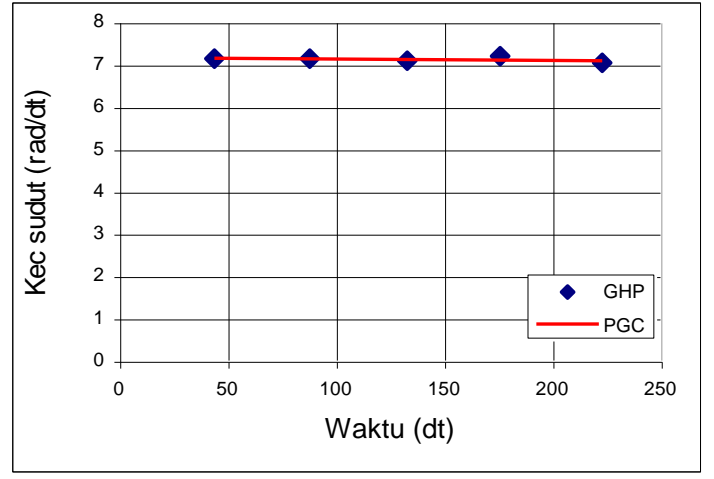

Gbr 3b. Hubungan kecepatan sudut dengan waktu

Berdasarkan Gambar 3a dapat dijelaskan bahwa waktu yang terbaca pada display digital sistem timer sebanding dengan jumlah cacahan. Hubungan antara waktu yang terbaca dengan jumlah cacahan dapat dirumuskan dalam bentuk:

$$
\text { ts }=0,892 \mathrm{n}-1
$$

Angka 0,892 pada persamaan menunjukan kemiringan dari garis lurus dan bernilai positif. Hal ini berarti semakin besar nilai jumlah cacahan yang dipilih maka semakin besar pula waktu yang terukur pada sistem timer.

Dari Gambar 3b, dapat dikemukakan dengan perubahan waktu ternyata kecepatan sudut tidak berubah. Hal ini membuktikan kecepatan sudut dari benda yang bergerak melingkar adalah konstan. Kecepatan sudut rata-rata didapatkan sebesar $7,117 \mathrm{rad} / \mathrm{dt}$.

Variasi lain dari gerak melingkar dilakukan dengan mengubah pemberian tegangan pada motor DC. Dengan perubahan pemberian tegangan menyebabkan kecepatan sudut dan kecepatan linear juga akan berubah. Hubungan antara waktu yang terbaca pada sistem timer dengan tegangan pada motor ditampilkan pada Gambar 4 


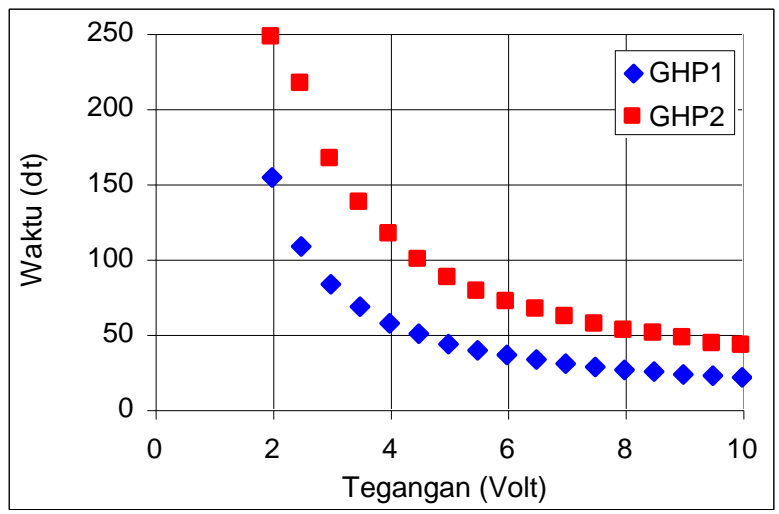

Gambar 4. Hubungan antara waktu dengan tegangan pada motor

Pada tegangan lebih rendah terlihat waktu yang terbaca pada sistem timer berkurang dengan cepat, dan apabila tegangan pada motor DC ditambah ternyata waktu berkurang dengan lambat. GHP 1 adalah garis hasil pengukuran untuk pemilihan jumlah cacahan 50, sedangkan GHP2 untuk pemilihan jumlah cacahan 100. Dari grafik juga dapat diungkapkan bahwa untuk pemberian suatu tegangan pada motor, waktu yang diperlukan untuk jumlah cacahan yang banyak lebih lama dari jumlah cacahan yang sedikit.

Jumlah cacahan dan waktu yang terukur pada sistem timer dapat dikonversi ke dalam bentuk frekuensi putaran. Kemudian frekuensi dapat dikonversi ke dalam bentuk kecepatan sudut dan kecepatan linear sesuai dengan hubungan antara besaran. Hubungan kecepatan sudut dan kecepatan linear dengan tegangan dapat diperhatikan pada Gambar 5

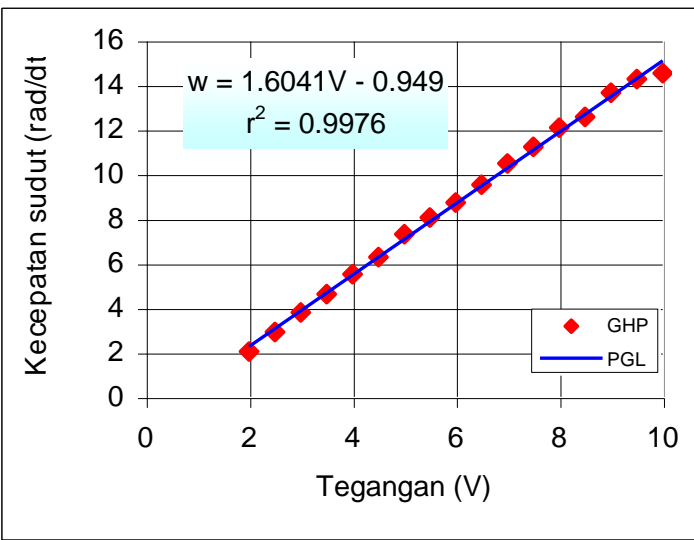

Gbr 5a. Hubungan Kecepatan Sudut Dengan Tegangan

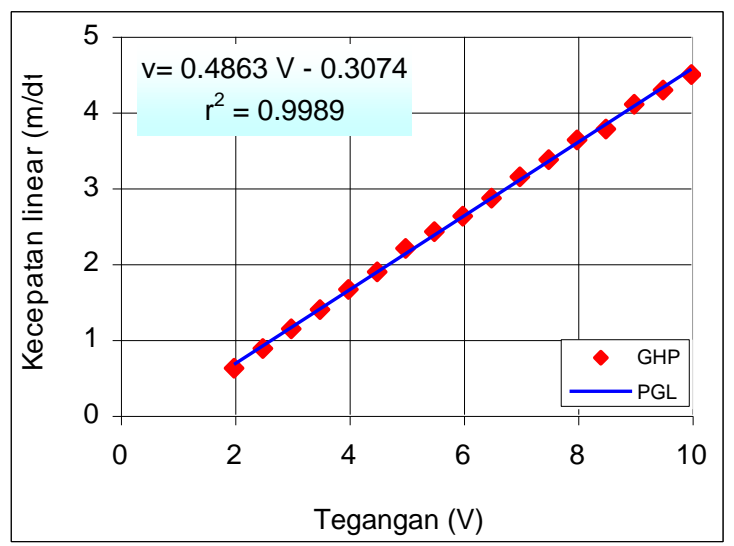

Gbr 5b. Hubungan Kecepatan Linear Dengan Tegangan 
Dari Gambar 5a dan 5b dapat dikemukakan bahwa kecepatan sudut dan kecepatan linear pada gerak melingkar sebanding dengan tegangan yang diberikan pada motor DC. Melalui pendekatan garis lurus dapat ditentukan bentuk hubungan antara kecepatan sudut dan kecepatan linear dengan tegangan seperti:

$$
\begin{aligned}
& \omega=1.604 V-0,949 \\
& v=0,486 V-0,307
\end{aligned}
$$

Dari persamaan dapat dijelaskan semakin besar tegangan yang diberikan pada motor DC menyebabkan kecepatan sudut dan kecepatan linear juga semakin besar. Angka 1,604 dan 0,486 masing-masing menyatakan gradien dari garis lurus dari hubungan antara besaran. Pada persamaan juga dapat diungkapkan bahwa nilai tegangan minimum yang diperlukan untuk menghasilkan kecepatan sudut nol adalah 0,592 Volt. Nilai koefisien determinasi dari hubungan antara kedua besaran masing-masing didapatkan 0,998 dan 0,999. Hal ini berarti sekitar 99, $9 \%$ perubahan kecepatan sudut dan kecepatan linear dari gerak melingkar disebabkan oleh perubahan tegangan yang diberikan pada motor DC.

Berdasarkan analisis yang telah dilakukan baik secara grafik maupun analisis teori kesalahan secara umum dapat dikatakan bahwa tujuan yang diinginkan dari penelitian ini telah dapat dicapai. Pertama, sistem timer dikendalikan counter memiliki ketepatan dan ketelitian yang tinggi dalam menentukan jumlah cacahan dan mengukur waktu untuk setiap pemilihan cacahan. Kedua, sistem timer dikendalikan counter dapat digunakan untuk menentukan parameter gerak melingkar beraturan meliputi: perioda, frekuensi, kecepatan sudut, dan kecepatan linear. Namun berdasarkan hasil pengamatan dalam aplikasi sistem timer dikendalikan counter pada gerak melingkar masih ditemukan dua kelemahan yaitu: nilai skala terkecil pada timer baru $1 \mathrm{dt}$, kecepatan putar yang besar belum dapat terdeteksi oleh sistem, dan untuk suatu nilai tegangan putaran motor kadang-kadang tidak stabil. Untuk itu perlu 
pemikiran lebih lanjut dalam pengembangan sistem timer dikendalikan counter dan aplikasinya pada gerak periodik khususnya pada gerak melingkar.

\section{Kesimpulan}

Berdasarkan hasil dan pembahasan yang telah dilakukan terhadap sistem pengaturan waktu deskrit berbasis mikrokontroler dapat dikemukakan kesimpulan sebagai berikut:

1. Ketepatan dan ketelitian dari sistem timer dikendali kan counter dalam mencacah dan mengukur waktu untuk setiap pemilihan jumlah cacahan termasuk tinggi.

2. Untuk suatu nilai tegangan pada motor DC, waktu pada digital timer bertambah secara linear dengan jumlah cacahan dan kecepatan sudut dari gerak adalah konstan.

3. Untuk suatu pemilihan jumlah cacahan waktu yang terbaca pada timer berkurang dengan cepat pada tegangan lebih rendah dan berkurang lebih lambat pada tegangan lebih tinggi.

4. Kecepatan sudut dan kecepatan linear pada gerak melingkar beraturan bertambah secara linear dengan pertambahan tegangan pada motor DC.

\section{DAFTAR PUSTAKA}

Agfianto, E. P. (2002). Belajar Mikrokontroler AT89C51/52/55 (Teori dan Aplikasi). Gava Media, Yogyakarta

Ayala, K. J, (1997). The 8051 Microcontroller: Architecture, Programming, \& Application. West Publishing Company.

Iovine, J. (2002). PIC Microcontroller Project Book. MC Graw Hill Book Company, USA

Lonnie, C. L. (1986). Fundamentals Of Digital Signal Processing. Harper \& Row Publisher. Inc, New york

Ogata, K. 1991. Teknik Kontrol Automatik. Jilid I, Erlangga, Jakarta. 
Mackenzie, S. I. (1995). The 8051 Microcontroller. New Jersey Colombue, Ohio

Ridwan. (1999). Dasar - Dasar Pengaturan. Universitas Negeri Padang, Padang

Rini, S, (2004). Pengembangan Sistem Pengaturan Waktu Diskrit Delapan Selektor Berbasis Mikrokontroler AT89C51 dan Aplikasi. Jurusan Fisika Fakultas Matematika dan Ilmu Pengetahuan Alam, Universitas Begeri Padang.

Sutrisno. (1987). Elektronika Lanjut Teori dan Penerapan. ITB, Bandung

Spasov, P. (1996). Microcontroller Technology: The 68HC11. Prentice Hall International, INC.

Tocci, R. J, (1995). Digital Systems: Principles and Applications. Prentice-Hall International, Inc. 